Int. J. Odontostomat.,

13(4):481-485, 2019.

\title{
Gingival Melanin Depigmentation With Diode Laser - Case Report
}

\author{
Despigmentación Melánica Gingival con Láser de Diodo - Relato de Caso
}

Fabiano Vassoler'; Eduardo Dall Magro'; Alessandra Kuhn-Dall Magro'; Rafael Rodrigues
Pessoa de Lacerda²; Luiz Renato Paranhos²; Pâmela Letícia Santos ${ }^{3}$ \& João Paulo De Carli ${ }^{1}$

VASSOLER, F.; MAGRO, E. D.; MAGRO, A. K.; DE LACERDA, R. R. P.; PARANHOS, L. R.; SANTOS, P. L. \& DE CARLI, J. P. Gingival melanin depigmentation with diode laser - case report. Int. J. Odontostomatol., 13(4):481-485, 2019.

ABSTRACT: The pigmented lesions of the oral cavity may be endogenous or exogenous. Endogenous lesions are benign and usually caused by melanin, and they are called gingival melanin pigmentations. Among the options for depigmenting these areas, laser therapy stands out for being a minimally invasive procedure. This study aims to report a clinical case of the gingival depigmentation technique using a high-power diode laser in the anterior maxillary region, for the ablation of the pigmented tissue to improve gingival aesthetics. The patient had an aesthetic complaint of the darkened aspect of the gingiva in the anterior maxillary and mandibular portions. After local anesthesia, we started depigmentation with high-power diode laser and performed ablation from the attached gingiva toward the free marginal gingiva. The patient returned after 30 and 180 days presenting healthy gingiva and absence of melanin repigmentation. Thus, we concluded that the diode laser was a good alternative for melanin depigmentation because it is a procedure with lower morbidity and satisfactory postoperative results.

KEY WORDS: depigmentation, hyperpigmentation, laser, repigmentation.

\section{INTRODUCTION}

The smile is a manifestation of self-confidence that involves aesthetic and psychological factors, and it includes teeth, lips, and gingival tissue. The color of the gingival tissue is usually pink, but it may be darker in some cases, also known as gingival hyperpigmentation (Suragimath et al., 2016).

Gingival color relates to the dimension of blood vessels, thickness and degree of epithelial keratinization, and pigments. Melanin stands out among the pigments, considering it is a natural dye from melanocytes and present in the basal and suprabasal layers of the gingival epithelium. Several factors affect the darkened color of gingiva, including: (1) drugs; (2) ingestion of heavy metals; (3) genetics; (4) endocrine disorders; (5) ultraviolet rays; (6) inflammation; (7) smoking; and (8) others (Pavlic et al., 2018).

Gingival hyperpigmentation causes aesthetic complaints, especially from patients with a gummy smile or excessive gingival exposure when smiling. The depigmentation treatment aims to remove melanin, and the techniques proposed include the scalpel technique (gold standard), gingivectomy, grafting, electrosurgery, cryosurgery, and laser (Suragimath et al.; Bakutra et al., 2017).

Currently, laser therapy has stood out, which works on melanocytes that absorb light and transform it into energy. Its effectiveness relates to the wavelength of apatite and water. For gingival depigmentation, the lasers mostly used are the diode, carbon dioxide (CO2), and Neodymium-YAG (yttrium aluminum garnet) (Suragimath et al.; Bakutra et al.).

Considering the aesthetic complaint of patients with gingival hyperpigmentation and the advantages of laser therapy, this study aimed to describe the clinical case of gingival depigmentation using diode laser.

\footnotetext{
${ }^{1}$ Department of Dentistry, School of Dentistry, University of Passo Fundo, Passo Fundo, RS, Brazil.

${ }^{2}$ Department of Preventive and Community Dentistry, School of Dentistry, Federal University of Uberlândia, Uberlândia, Minas Gerais, Brazil.

${ }^{3}$ Department of Health Sciences, University of Araraquara, Araraquara, SP, Brazil.
} 


\section{CASE REPORT}

Ethical Aspects and Study Protocol. We conducted this case in accordance with the Declaration of Helsinki and the patient signed an informed consent form for the dental treatment and the scientific report of the case. We prepared this case report in accordance with the CARE guidelines (Gagnier et al., 2013).

Patient Information and Clinical Findings. Male patient, 27 years old, attended the School of Dentistry of the University of Passo Fundo, RS, Brazil, complaining of "darkened gingiva" and reporting that pigmentation was impairing his smile.
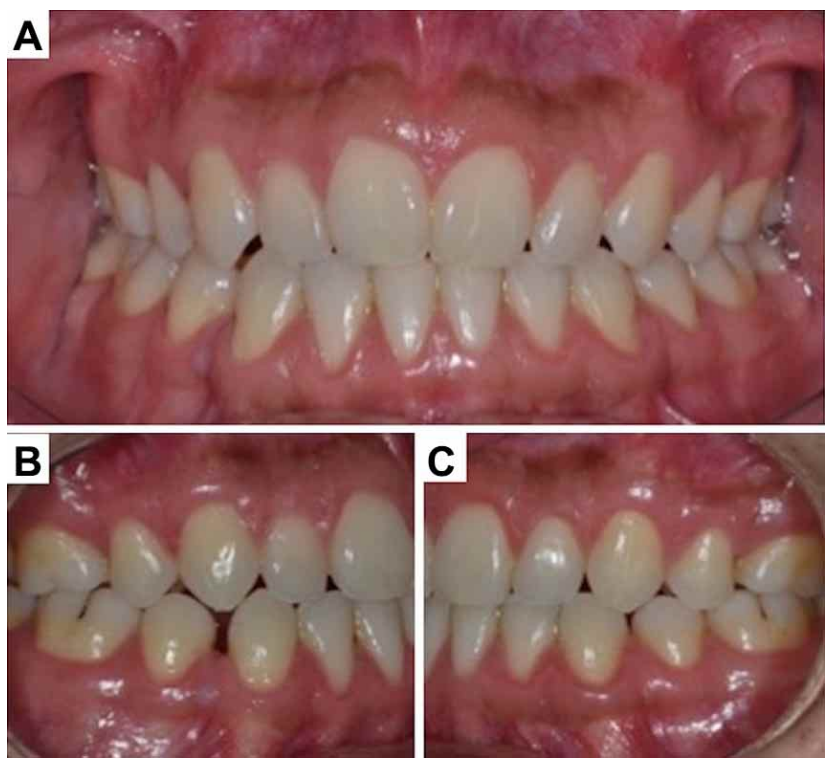

Fig. 1. Preoperative clinical aspect of the gingiva with melanin hyperpigmentation. (1A) - Frontal view; (1B and 1C) - Lateral view.

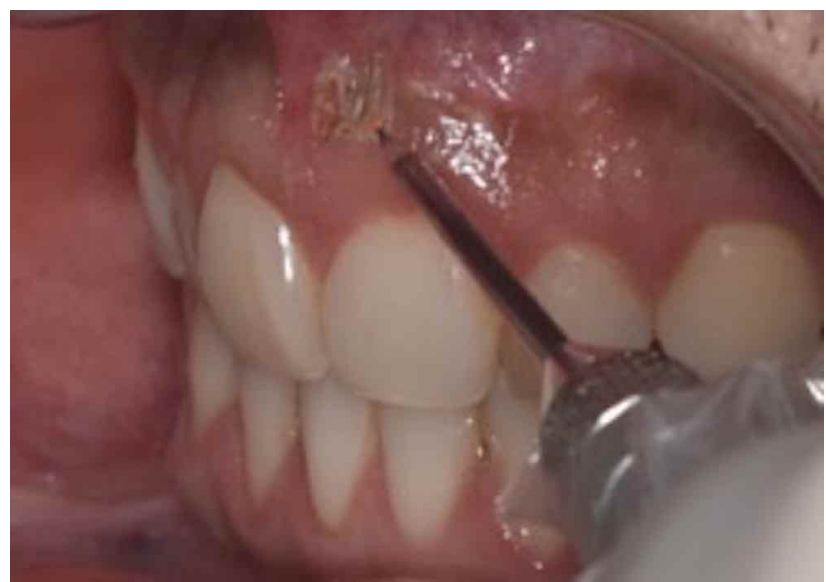

Fig. 2. Ablation started from the attached gingiva toward the free marginal gingiva.
The clinical examination diagnosed a gingival melanin pigmentation in the anterior maxillary and mandibular regions (Fig. 1). For the treatment, we offered the patient a diode laser pigmentation.

Therapeutic Intervention. After antisepsis with $0.12 \%$ and $2 \%$ chlorhexidine digluconate, intra- and extraorally, respectively, we anesthetized the patient from the upper left first premolar to the upper right first premolar using the infraorbital anesthetic technique with $2 \%$ mepivacaine and 1:100,000 adrenaline as an anesthetic. The mandible received the terminal infiltration technique in the bottom groove from the left canine to the right canine, using the same anesthetic.

For the laser therapy, the patient and the surgical team used protection goggles. Depigmentation occurred with a diode laser surgical appliance (wavelength of $980 \mathrm{~nm}$ and power of $1200 \mathrm{~mW}$ ).
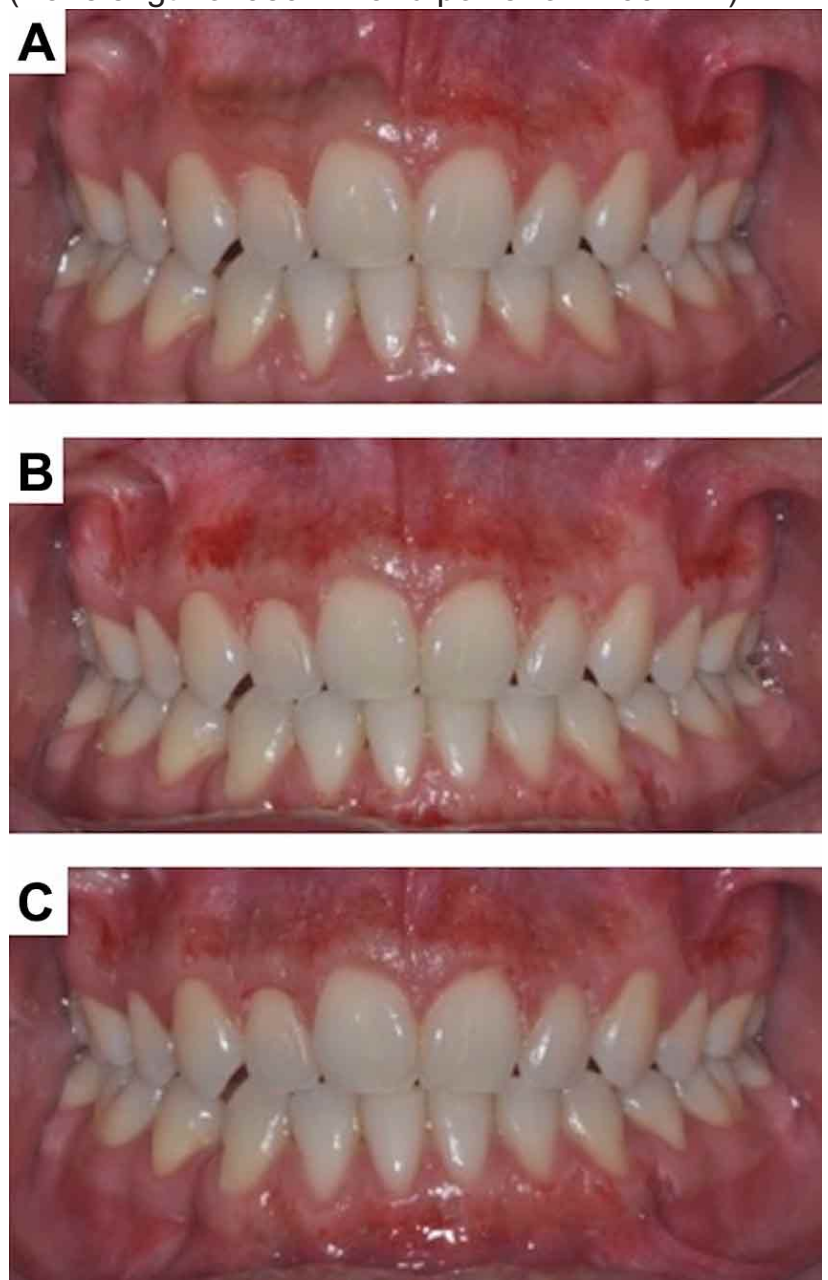

Fig. 3. (A) Ablation performed first in the upper left quadrant to the first molar; (B) Ablation performed in the upper right quadrant to the first molar; (C) Ablation performed in the lower quadrant from canine to canine. 
A flexible optical fiber tip emitted the laser light continuously. The laser setting consisted of energy of $215 \mathrm{~J}$, power of $1200 \mathrm{~mW}$, and time of 3 minutes. Ablation started from the attached gingiva toward the free marginal gingiva, according to Fig. 2.

First, we performed ablation in the upper left quadrant to the first molar (Fig. 3a), then the upper right quadrant to the first molar (Fig. 3b), and lastly in the lower quadrant from canine to canine (Fig. 3c).

Follow-up and Outcomes. We performed circular and intermittent movements being careful not to reach adjacent and subjacent structures. We used a gauze moistened with $0.9 \%$ saline solution to remove the epithelial tissue for improved visualization.

After total ablation of the pigmented mucosa, the patient received postoperative instructions and the prescription of an analgesic (Fig. 4). The patient

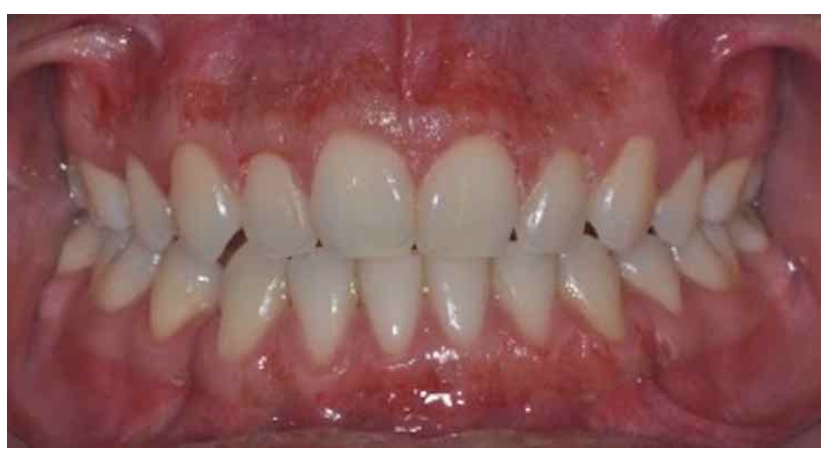

Fig. 4. Postoperative clinical aspect immediately after melanin depigmentation.
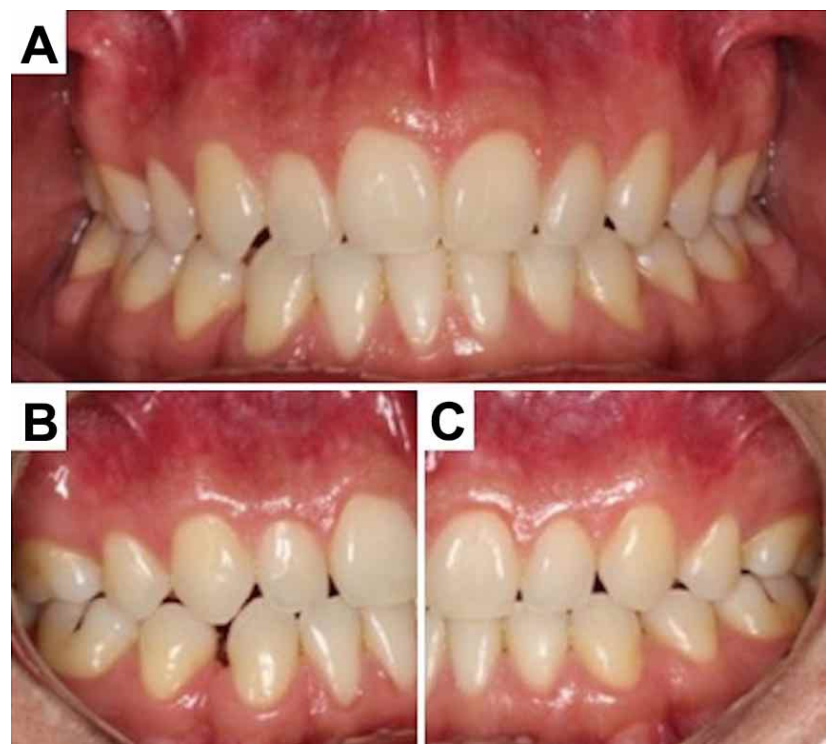

Fig. 5. Clinical aspect 30 days after the procedure of melanin depigmentation. returned after 30 and 180 days presenting healthy gingiva and the absence of melanin repigmentation (Figs. 5 and 6).

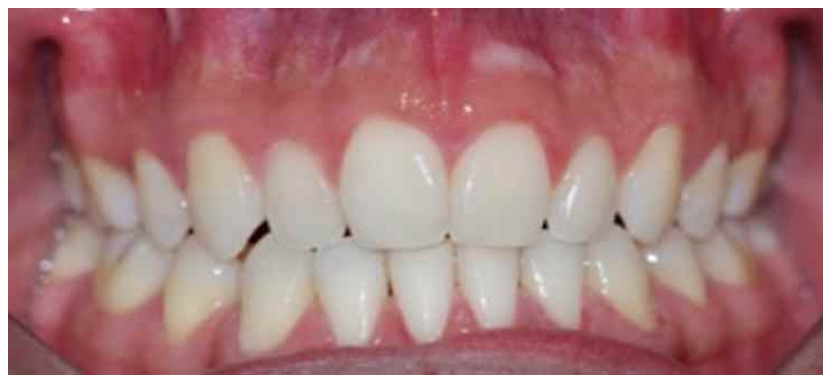

Fig. 6. Clinical aspect 180 days after the procedure of melanin depigmentation.

Table I. Main characteristics of the pigmented lesions of the cavity found in the patient of the case reported.

\begin{tabular}{llc}
\hline Characteristics of pigmented lesions of the cavity & Presence \\
\hline \multirow{3}{*}{ Characteristics } & Physiological changes & Yes \\
& Systemic manifestations & Yes \\
& Endogenous & Yes \\
& Exogenous & Yes \\
& Darkened spots & Yes \\
Pigmentation & Oral mucosa & Yes \\
& Tongue & Yes \\
& Lips & Yes \\
& Palate & Yes \\
& Drugs & Yes \\
Influential factors & Smoking & Yes \\
& Genetics & Yes \\
& Disorders & Yes \\
& Inflammation & Yes \\
\hline
\end{tabular}

\section{DISCUSSION}

According to Suragimath et al., the prevalence of melanin pigmentation ranges between $0 \%$ and 89 $\%$ in different populations regarding ethical factors. Gingival hyperpigmentation is called physiological or racial pigmentation because it occurs as a genetic trait in some populations (Dummett \& Barens, 1971).

The patient of the present report is a man. Other studies reported melanin pigmentation (MP) in different sexes. The literature is certain to affirm that MP affects both men and women equally or in the same proportion (Sims, ek Kaya et al., 2012; Soliman et al., 2014; Ponnaiyan et al., 2014). Regardless of sex, MP is more prevalent in black individuals.

Depigmentation occurred with a surgical diode laser appliance with a wavelength of $980 \mathrm{~nm}$, power 
of $1200 \mathrm{~mW}$, and $215 \mathrm{~J}$ of energy. In contrast, other authors (Murthy et al., 2012; Simsek Kaya et al.; El Shenawy et al., 2015) used diode laser with powers of $1.5 \mathrm{~W}, 1 \mathrm{~W}$, and $3 \mathrm{~W}$, and wavelengths of 810 $\mathrm{nm}, 808 \mathrm{~nm}$, and $980 \mathrm{~nm}$, respectively. There are other depigmentation techniques such as electrosurgery, Nd:YAG laser, cryosurgery, scalpel removal, and rotary abrasion, addressed by Murthy et al., Gupta et al. (2015), Chandna \& Kedige (2015), and Patil et al. (2015), who used high-power diode laser because of hemostasis and lower postoperative morbidity.

According to Ali et al. (2018), gingival melanin depigmentation with laser presents several advantages in relation to other therapies, such as hemostasis, visibility in the surgical field, and minimum discomfort to patients. Moreover, the diode laser has an affinity with hemoglobin and melanin, and it does not interact over hardened dental tissues. Therefore, it is highly indicated for cutting/coagulating the gingiva and oral mucosa, as well as for curettage and sulcular debridement.

We performed infiltration anesthesia with $2 \%$ mepivacaine before starting the surgery due to the presence of adrenaline as a vasoconstrictor, enhancing the anesthetic effect and reducing transoperative bleeding. Similarly, authors (Kaur \& Das, 2012; Soliman et al.; Ponnaiyan et al.; Murthy et al.; Gupta et al.; Basha et al., 2015) also performed infiltration anesthesia before the procedures. However, Sims, ek Kaya et al. did not perform anesthesia before the procedure, because one of the objectives of the study was to assess trans- and postoperative pain, comparing diode laser and Er:YAG laser.

Melanin depigmentation occurred in the upper and lower quadrants, similar to other authors (Gupta, 2011, Soliman et al.). The literature review shows that some authors (Simsek Kaya et al.; Soliman et al.; Ponnaiyan et al.; Grover et al., 2014; Elevarasu et al., 2015) performed depigmentation only in the upper quadrant because patients presented a high smile line and melanin pigmentation only in the maxillary anterosuperior region.

During ablation with the diode laser, we used a gauze moistened with $0.9 \%$ saline solution to remove the epithelial tissue and reduce bleeding, which was similar to authors Ponnaiyan et al., El Shenawy et al., Elevarasu et al., Grover et al. and Derikvand et al. (2016).
In this clinical case, we completed depigmentation in one session, agreeing with authors Simsek Kaya et al., Ponnaiyan et al., El Shenawy et al., Elevarasu et al. and Basha et al. However, Soliman et al. performed the procedure in two sessions to remove the pigmentations satisfactorily, because patients presented melanin pigmentation in the gingiva and cheek mucosa.

Melanin absorbs the laser light with a wavelength of $980 \mathrm{~nm}$ and converts the light energy into heat by photothermolysis. When reaching a temperature of 100 up to $150^{\circ} \mathrm{C}$, this heat causes protein denaturation, tissue vaporization, and coagulation, thus reducing trans- and postoperative bleeding, according to most authors cited.

The patient returned after 30 and 180 days for assessment, presenting healthy gingiva, without maxillary and mandibular edema and pigmentation. The results of this study were similar to those obtained by Thangavelu et al. (2012), Murthy et al., Sims,ek Kaya et al., Soliman et al., El Shenawy et al., Elevarasu et al., and Grover et al., who did not present repigmentation up to the third month after depigmentation with diode laser within the observation period determined. Such period was halfway of the assessment of the present study. Gupta did not observe repigmentation in the patient up to 15 months after depigmentation with the diode laser, confirming the longevity of the result and the efficiency of the highpower laser technique.

\section{CONCLUSION}

Using a high-power diode laser was a safe and effective treatment modality that offered adequate final aesthetics with minimum discomfort to patients with gingival hyperpigmentation.

VASSOLER, F.; MAGRO, E. D.; MAGRO, A. K.; DE LACERDA, R. R. P.; PARANHOS, L. R.; SANTOS, P. L. \& DE CARLI, J. P. Despigmentación melánica gingival con láser de diodo - Relato de caso. Int. J. Odontostomatol., 13(4):481-485, 2019.

RESUMEN: Las lesiones pigmentadas de la cavidad oral pueden ser endógenas o exógenas. Las endógenas son benignas y generalmente causadas por la melanina, denominándose pigmentaciones melánicas gingivales. Entre las opciones para la despigmentación de estas regiones, se 
destaca la laserterapia, por ser un procedimiento poco invasivo. Este trabajo tuvo como objetivo relatar un caso clínico de la técnica de despigmentación gingival utilizando láser de diodo de alta intensidad en la región anterior de los maxilares para ablación del tejido pigmentado con la finalidad de mejorar la estética gingival. El paciente presentaba como queja estética el aspecto oscurecido de la encía en la región anterior de la maxila y de la mandíbula. Tras aplicar anestesia local, se inició la despigmentación con láser de diodo de alta intensidad, siendo que la ablación se realizó a partir de la encía insertada hacia la encía marginal libre. El paciente regresó tras 30 y 180 días, presentando encía saludable y con ausencia de repigmentación melánica. Así fue posible concluir que el láser de diodo mostró ser una buena alternativa para la despigmentación melánica, ya que se presentó como un procedimiento con menor morbidad y buen resultado postoperatorio.

PALABRAS CLAVE: despigmentación, hiperpigmentación, láser, repigmentación.

\section{REFERENCES}

Ali, S.; Jha, P. \& Khan, U. Esthetic management of a patient with severely fluorosed enamel and pigmented gingiva: A conservative approach. Contemp. Clin. Dent., 9(2):323-5, 2018.

Bakutra, G.; Shankarapillai, R.; Mathur, L. \& Manohar, B. Comparative evaluation of diode laser ablation and surgical stripping technique for gingival depigmentation: A clinical and immunohistochemical study. Int. J. Health Sci. (Qassim), 11(2):518, 2017.

Basha, M. I.; Hegde, R. V.; Sumanth, S.; Sayyed, S.; Tiwari, A. \& Muqlikar, S. Comparison of Nd:YAG laser and surgical stripping for treatment of gingival hyperpigmentation: A clinical trial. Photomed. Laser Surg., 33(8):424-36, 2015.

Chandna, S., \& Kedige, S. D. Evaluation of pain on use of electrosurgery and diode lasers in the management of gingival hyperpigmentation: A comparative study. J. Indian Soc. Periodontol., 19(1):49-55, 2015.

Derikvand, N.; Chinipardaz, Z.; Ghasemi, S. \& Chiniforush, N. The versatility of $980 \mathrm{~nm}$ diode laser in dentistry: A case series. J. Lasers Med. Sci., 7(3):205-8, 2016.

Dummett, C. O. \& Barens, G. Oromucosal pigmentation: an updated literary review. J. Periodontol., 42(11):726-36, 1971.

El Shenawy, H. M.; Nasry, S. A.; Zaky, A. A. \& Quriba, M. A. Treatment of gingival hyperpigmentation by diode laser for esthetical purposes. Open Access Maced. J. Med. Sci., 3(3):447-54, 2015.

Gagnier, J. J.; Kienle, G.; Altman, D. G.; Moher, D.; Sox, H.; Riley, D. \& CARE Group. The CARE Guidelines: Consensus-based Clinical Case Reporting Guideline Development. Glob. Adv. Health Med., 2(5):38-43, 2013.

Grover, H. S.; Dadlani, H.; Bhardwaj, A.; Yadav, A. \& Lal, S. Evaluation of patient response and recurrence of pigmentation following gingival depigmentation using laser and scalpel technique: $A$ clinical study. J. Indian Soc. Periodontol., 18(5):586-92, 2014.

Gupta, G. Management of gingival hyperpigmentation by semiconductor diode laser. J. Cutan. Aesthet. Surg., 4(3):20810, 2011.

Gupta, G.; Kumar, A.; Khatri, M.; Puri, K.; Jain, D. \& Bansal, M. Comparison of two different depigmentation techniques for treatment of hyperpigmented gingiva. J. Indian Soc. Periodontol., 18(6):705-9, 2015.

Murthy, B. M.; Kaur, J. \& Das, R. Treatment of gingival hyperpigmentation with rotary abrasive, scalpel, and laser techniques: A case series. J. Indian Soc. Periodontol., 16(4):6149, 2012.

Patil, K. P.; Joshi, V.; Waghmode, V. \& Kanakdande, V. Gingival depigmentation: A split mouth comparative study between scalpel and cryosurgery. Contemp. Clin. Dent., 6(Suppl. 1):S97-101, 2015.

Pavlic, V.; Brkic, Z.; Marin, S.; Cicmil, S.; Gojkov-Vukelic, M. \& Aoki, A. Gingival melanin depigmentation by Er:YAG laser: A literature review. J. Cosmet. Laser Ther., 20(2):85-90, 2018.

Ponnaiyan, D.; Jegadeesan, V.; Perumal, L. \& Anusha, A. Correlating skin color with gingival pigmentation patterns in South Indians a cross sectional study. Oral Health Dent. Manag., 13(1):132-6, 2014.

Simsek Kaya, G.; Yapici Yavuz, G.; Sümbüllü, M. A. \& Dayi, E. A comparison of diode laser and Er:YAG lasers in the treatment of gingival melanin pigmentation. Oral Surg. Oral Med. Oral Pathol. Oral Radiol., 113(3):293-9, 2012.

Soliman, M. M.; Al Thomali, Y.; Al Shammrani, A. \& El Gazaerly, H. The use of soft tissue diode laser in the treatment of oral hyper pigmentation. Int. J. Health Sci. (Qassim), 8(2):133-40, 2014.

Suragimath, G.; Lohana, M. H. \& Varma, S. A split mouth randomized clinical comparative study to evaluate the efficacy of gingival depigmentation procedure using conventional scalpel technique or diode laser. J. Lasers Med. Sci., 7(4):227-32, 2016.

Thangavelu, A.; Elevarasu, S., \& Jayapalan, P. Pink esthetics in periodontics - Gingival depigmentation: A case series. J. Pharm. Bioallied Sci., 4(Suppl. 2):S186-90, 2012.

Corresponding author:

Professor Luiz Renato Paranhos

Av. Pará, 1720 , Bloco $2 \mathrm{G}$, sala 1 , Umuarama.

ZIP code: 38405-320.

Uberlândia, MG

BRAZIL

Email: paranhos.Irp@gmail.com

Received: 12-06-2019

Accepted: 02-07-2019 